\title{
James Spence Medallist, 1980
}

\author{
James Mourilyan Tanner
}

James Tanner spent much of his childhood abroad, in the baggage train of the British Army; when he was 9 years old the family returned to their home in east Devon and he began his schooling. He attended Marlborough College from 1934 to 1938 on a scholarship reserved for the sons of Army officers. Having specialised first in modern languages and then in mathematics and engineering, he found himself ill-equipped when at 17 he decided on a career in medical research. After a 6-month premedical course at the Unjversity of Exeter (then the College of the South West) he reached medical school in 1939 by means of a scholarship for athletics: this was at St Mary's Hospital (London University). In 1941 he went to the USA in the first batch of war-time Rockefeller students; he took most of his clinical course in Philadelphia at the University of Pennsylvania, and interned on the Osler medical service at Johns Hopkins Hospital.

At St Mary's, Professor A St G Huggett had initiated him (as he initiated Kenneth Cross, last year's James Spence Medallist) into physiological research work and in Philadelphia, under Professor Isaac Starr, Tanner undertook his first serious research which led to a paper entitled 'The construction of normal standards for cardiac output in man.' After Johns Hopkins, he returned to London, completed his English qualification, and served as junior medical officer in the Emergency Medical Service at the war-time Maudsley Hospital at Mill Hill, working on the physiology and psychiatry of effort syndrome (the soldier's heart). He was subsequently junior psychiatrist at the Prisoner-of-War Rehabilitation Unit at Dartford, Kent, under Dr Maxwell Jones.

In 1946 he joined the Department of Human Anatomy at Oxford where, at the suggestion of Professor Le Gros Clark, he initiated a course on growth in children. This led to an invitation from Dr E R Bransby of the Ministry of Health to organise a long-term longitudinal growth study at Harpenden. He returned to London and taught endocrinology in the Sherrington School of Physiology at St Thomas's Hospital where he became increasingly concerned with child growth. In 1948 he was joined by $\mathbf{R} \mathbf{H}$ Whitehouse and their association has lasted to the present time.
His long connection with the Institute of Child Health started in 1951 when Sir Alan Moncrieff invited him to give a lecture on the growth of children in the British Postgraduate Federation Lecture Series: this lecture was the basis on which Growth at adolescence was written a few years later. In 1956 Dr Frank Falkner, who ran the longitudinal growth study started by Moncrieff at the Institute of Child Health, left for America and Tanner and Whitehouse moved over to the Institute where they eventually established a full-scale department of growth and development with financial help from the Nuffield Foundation. A few years later, encouraged by Dr George Newns, he returned to clinical work and started a growth disorder clinic in The Hospital for Sick Children. Here the expertise acquired in studying the normal was used to monitor the growth of children with disturbances, especially those with growth hormone deficiency, in the treatment of which the clinic played a pioneering and prominent role.

In 1966 he was designated Professor of Child Health and Growth at the Institute of Child Health, and the chair was made an established one by the University of London in 1977. He has always been a strong champion of the science of human biology; in 1958 he was one of the founder members of the Society for the Study of Human Biology, and is currently one of the editors of its journal Annals of

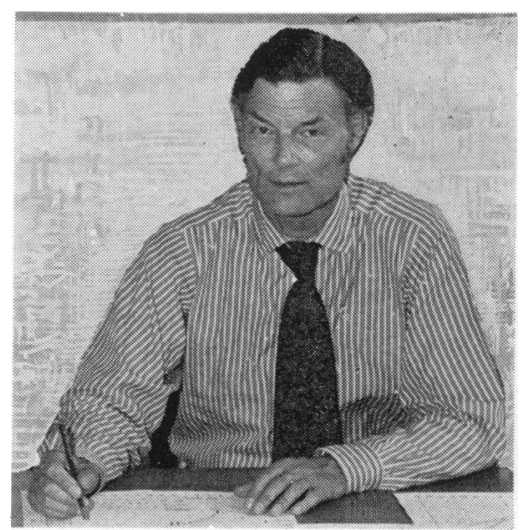


Human Biology. Many of his own publications have been in Archives of Disease in Childhood, where his studies on growth standards have appeared from 1952 up to the present day.

In presenting the James Spence medal to Professor Tanner at the annual general meeting of the British Paediatric Association at York on 17 April 1980, the President, Dr G M Komrower, spoke the following citation:

'Members of the Association and friends, may I present to you James Mourilyan Tanner, this year's James Spence medallist. This is the highest award the Association can make, and it is given for outstanding contributions to the advancement and clarification of paediatric knowledge. It is of interest to note that for the second successive year the medal has been given to someone working outside but alongside paediatrics, who was a student at St Mary's Hospital and a first class athlete.

'There are three factors that have made today's award possible: the first is Jim Tanner's fortuitous entry into medicine. In Sybille Bedford's biography of Aldous Huxley she mentioned Jim Tanner as one of the young men of the 'thirties who was greatly influenced by Huxley's writings. She has recently written to me that he was destined for the Army, a traditional family career, but gave this up and finally chose medicine. The second was Alan Moncrieff's foresight in taking him from the department of physiology at St Thomas's Hospital where he was working with Professor Barcroft and where he initiated the Harpenden Longitudinal Growth Study, to bring him to the Child Study Centre at the Institute of Child Health, where Jim subsequently established a department of growth and development. The third was Tanner's teamwork with Reg Whitehouse, which started at St Thomas's. This proved to be an excellent partnership; when one thinks of similar partnerships that have been outstanding in their particular walks of life, the names of Gilbert and Sullivan and Marks and Spencer come to mind, but the nearest that I could get was Rolls and Royce, who produced something that has been quite outstanding in the motor engine industry. Whitehouse, with his attention to detail and his precise measurement, and Tanner, with his flair and energy, together have introduced and then developed the science of auxology. Jim Tanner brought a new dimension into paediatrics, that of measurement, and coupled with this a great deal of work on other facets of growth such as his human growth hormone studies. He did this while developing his own unit for which he personally had to obtain considerable financial assistance.

'Unfortunately, I have not had the opportunity to know Jim Tanner let alone to work with him; nevertheless one gets a feeling of great intellectual energy as in addition to the hard work required for the promotion of his research, he has written scores of scientific papers and a number of books which have been published in many languages. I understand that he is a man difficult to know, and a hard taskmaster, but the discipline and precision in his unit has reaped its reward in that his department has produced a number of professors and readers in endocrinology, human biology, growth and development, as well as in cell biology. He also has seen the increasing activity of two general practitioners in the family-his wife and son.

'Jim Tanner is an extremely versatile individual, in addition to his sporting and intellectual activities he now is becoming an authority on agricultural equipment, and in his country cottage on the borders of Devon and Somerset is interested and enquiring into fish farming and solar energy. It would appear that as in his professional life, he intends to be self-sufficient in his retirement. As I indicated I have had to obtain my knowledge from his friends, and the enthusiasm and sincerity of their comments has been very exciting. The quality of Jim Tanner's work is admired and respected by paediatricians the world over and it is for this reason that I am privileged to present to him on your behalf this James Spence medal.'

\section{James Spence Medallists}

1960 Professor A A Moncrieff

1961 Professor R A McCance

1963 Sir F Macfarlane Burnet

1964 Professor L S Penrose

1965 Dr Cicely D Williams

1967 Professor R R A Coombs

1968 Dr Mary D Sheridan

Dr D W Winnicott

1969 Dr G S Dawes

1970 Professor D V Hubble

1971 Dr W W Payne

1972 Dr R C Mac Keith

1973 Professor C A Clarke

1974 Dr J Bowlby

1976 Dr D M T Gairdner

1977 Professor R S Illingworth

1978 Dr S D M Court

1979 Professor K W Cross 